\title{
OPTIMALISASI PRODUKSI PUPUK MENGGUNAKAN METODE GOAL PROGRAMMING PADA PABRIK NPK PHONSKA I, II DAN III DEPARTEMEN PRODUKSI IIA PT. PETROKIMIA GRESIK
}

\author{
Puspitasari $^{1}$, Said Salim Dahda ${ }^{2}$, Elly Ismiyah $^{3}$ \\ ${ }^{1,2,3}$ Program Studi Teknik Industri Fakultas Teknik Universitas Muhammadiyah \\ Gresik \\ *Email: pus05031997@gmail.com
}

\begin{abstract}
ABSTRAK
PT. Petrokimia Gresik merupakan salah satu produsen pupuk terlengkap dan terbesar di Indonesia yang berada di bawah naungan PT. Pupuk Indonesia Holding Company. Untuk menunjang proses produksi PT. Petrokimia memiliki beberapa departemen produksi, salah satunya yaitu Departemen produksi II A. Departemen ini terdiri dari 3 pabrik yaitu NPK Phonska I, II dan III.Produk yang dihasilkan diantaranya yaitu Phonska Subsidi, NPK Kebomas dan Phonska Plus. Dalam pemenuhan produksi sering terjadi ketidaksesuaian antara rencana dan realisasi target produksi.

Goal programming adalah salah satu metode optimasi. Penelitian ini bertujuan untuk mengoptimalkan jumlah produksi Pupuk Phonska Subsidi, NPK Kebomas dan Phonska Plus pada periode Januari-Juni 2019 di Pabrik NPK Phonska I,II dan III. Sebelum melakukan optimasi dilakukan peramalan dengan metode time series. Kendala dalam penelitian ini adalah Jumlah Target Produksi,Ketersediaan Hari Kerja Mesin dan Ketersediaan bahan baku.

Dengan menggunakan metode ini diperoleh hasil optimal pada bulan Januari-Juni 2019. Jumlah Tonase yang dapat diproduksi untuk pupuk Phonska Subsidi yaitu

1.211.456 Ton dengan penyimpangan negative yaitu sebesar 0 Ton dari target yang ditentukan yaitu 1.211.456 Ton. Jumlah tonase yang dapat diproduksi untuk pupuk NPK Kebomas yaitu 182.978 Ton dari target yang ditentukan yaitu 182.978 Ton. Sedangkan jumlah tonase yang dapat diproduksi untuk pupuk Phonska Plus yaitu 53.572 Ton dari target yang ditentukan yaitu 53.572 Ton.
\end{abstract}

\section{Kata Kunci : Goal Programming, Peramalan, Optimasi, Penyimpangan.}

\section{PENDAHULUAN}

PT Petrokimia Gresik

merupakan produsen pupuk terlengkap dan terbesar di Indonesia yang berada di bawah naungan PT. Pupuk Indonesia Holding Company (PIHC). PT Petrokimia Gresik memiliki produk pupuk dan non pupuk. Unit produksi yang dimiliki PT. Petrokimia Gresik diantaranya yaitu Departemen Produksi II A yang terdiri dari Pabrik NPK Phonska I, II, III dan Pabrik Fosfat I yang memproduksi dengan sistem produksi Make To Stock (MTS) dan Make To Order (MTO). 
Data kapasitas produksi dari masing-masing pabrik dalam memproduksi masing-masing produk di Departemen produksi II A pada PT. Petrokimia Gresik dapat dilihat pada Tabel 1.1.

Tabel 1.1 Data kapasitas produksi di Departemen Produksi II A

\begin{tabular}{|c|c|c|c|}
\hline \multirow[t]{2}{*}{ Produk } & \multicolumn{3}{|c|}{ Pabrik } \\
\hline & $\begin{array}{c}\text { NPK } \\
\text { Phonska } \\
\text { I }\end{array}$ & $\begin{array}{c}\text { NPK } \\
\text { Phonska } \\
\text { II }\end{array}$ & $\begin{array}{c}\text { NPK } \\
\text { Phonska } \\
\text { III }\end{array}$ \\
\hline $\begin{array}{l}\text { Phonska } \\
\text { Subsidi }\end{array}$ & $\begin{array}{c}1.500 \\
\text { ton/hari } \\
\text { atau } \\
450.000 \\
\text { ton/tahun }\end{array}$ & $\begin{array}{c}2.000 \\
\text { ton/hari } \\
\text { atau } \\
600.000 \\
\text { ton/tahun }\end{array}$ & $\begin{array}{c}2.000 \\
\text { ton/hari } \\
\text { atau } \\
600.000 \\
\text { ton/tahun }\end{array}$ \\
\hline $\begin{array}{l}\text { NPK } \\
\text { Kebomas }\end{array}$ & $\begin{array}{c}1.200 \\
\text { ton/hari } \\
\text { atau } \\
360.000 \\
\text { ton/tahun }\end{array}$ & $\begin{array}{c}1.500 \\
\text { ton/hari } \\
\text { atau } \\
450.000 \\
\text { ton/tahun }\end{array}$ & $\begin{array}{c}1.500 \\
\text { ton/hari } \\
\text { atau } \\
450.000 \\
\text { ton/tahun }\end{array}$ \\
\hline $\begin{array}{l}\text { Phonska } \\
\text { Plus }\end{array}$ & $\begin{array}{l}1.050 \\
\text { ton/hari } \\
\text { atau } \\
315.000 \\
\text { ton/tahun }\end{array}$ & $\begin{array}{c}1.400 \\
\text { ton/hari } \\
\text { atau } \\
420.000 \\
\text { ton/tahun }\end{array}$ & $\begin{array}{c}1.350 \\
\text { ton/hari } \\
\text { atau } \\
405.000 \\
\text { ton/tahun }\end{array}$ \\
\hline
\end{tabular}

(Sumber: PT. Petrokimia Gresik)

Produk yang dihasilkan di Pabrik NPK Phonska I,II dan III ini salah satunya adalah pupuk bersubsidi yaitu pupuk Phonska subsidi. Dengan adanya pertumbuhan produksi di lapangan usaha pertanian tidak menutup kemungkinan permintaan pupuk di Unit Pabrik NPK Phonska I,II dan III akan meningkat seiring dengan pertumbuhan hasil produksi para petani di Indonesia, maka PT. Petrokimia Gresik harus menjaga kelancaran proses produksinya supaya dapat memenuhi permintaan dari konsumen. Dalam pemenuhan target produksi di Pabrik Phonska I, II dan III ini sering terjadi ketidaksesuaian antara rencana dan realisasi target produksi, sering terjadi kelebihan dan kekurangan hasil produksi di Pabrik NPK Phonska I, II dan III. Terlebih jika produk tersebut adalah pupuk bersubsidi yang pengadaan dan Penyalurannya diawasi oleh pemerintah. Perusahaan tidak mengharapkan terjadinya kelebihan ataupun kekurangan pada pencapaian realisasi produksi karena hal tersebut secara tidak langsung akan merugikan perusahaan.

Salah satu metode yang digunakan dalam mengoptimalisasi produksi adalah Goal Programming. Menurut Mulyono (2014) Goal Programming adalah pengembangan dari Linier Programming yang semua tujuannya digabungkan dalam sebuah fungsi tujuan dengan mengekspresikan tujuan tersebut ke 
dalam bentuk sebuah kendala (goal constraint) dengan memasukkan suatu variabel simpangan (deviational variable) dalam kendala tersebut untuk mengetahui seberapa jauh simpangan dalam fungsi tujuan.

Oleh karena itu dalam penelitian ini, untuk menyelesaikan suatu masalah dimana target produksi harus terpenuhi dengan kendala yang ada, maka dipilih suatu metode yang dapat menyelesaikan permasalahan dengan multi variable maka dipilihlah metode goal programming. Sebelum membuat model goal programming akan dilakukan peramalan pada periode Januari-Desember 2019 pada masing-masing dengan menggunakan perangkat lunak Minitab 16, sedangkan penentuan produk subsidi ditentukan oleh pemerintah. Dan dalam pengolahan data penyelesaian model matematisnya menggunakan perangkat lunak LINGO 17.0.

\begin{tabular}{|c|c|c|c|c|c|c|c|}
\hline \multirow{2}{*}{ Pabrik } & \multirow{2}{*}{ Bulan } & \multicolumn{2}{|c|}{ Phonska Subsidi } & \multicolumn{2}{|c|}{ NPK Kebomas } & \multicolumn{2}{|c|}{ Phonska plus } \\
\hline & & Target & Realisasi & Target & Realisasi & Target & Realisasi \\
\hline \multirow{9}{*}{$\begin{array}{c}\text { NPK } \\
\text { Phonska } \\
\text { I }\end{array}$} & Januari & 39.000 & 45.902 & - & - & - & - \\
\hline & Februari & 34.000 & 39.020 & - & - & - & - \\
\hline & Maret & 40.000 & 15.788 & - & - & - & - \\
\hline & April & 38.000 & 31.819 & - & - & - & - \\
\hline & Mei & 40.000 & 42.456 & - & - & - & - \\
\hline & Juni & 38.000 & 41.439 & - & - & - & - \\
\hline & TOTAL & 229.000 & 216.424 & - & - & - & - \\
\hline & Keterangan & \multicolumn{2}{|c|}{ Tidak Terpenuhi } & \multicolumn{2}{|c|}{-} & \multicolumn{2}{|c|}{-} \\
\hline & Selisih & \multicolumn{2}{|c|}{$\longrightarrow$} & \multicolumn{2}{|c|}{ - } & \multicolumn{2}{|c|}{-} \\
\hline \multirow{8}{*}{$\begin{array}{c}\text { NPK } \\
\text { Phonska } \\
\text { II }\end{array}$} & Januari & 5.000 & 7.130 & 20.000 & 34.580 & 11.000 & 4.682 \\
\hline & Februari & 31.000 & 48.418 & - & - & 11.000 & - \\
\hline & Maret & 1.000 & 21.332 & 25.000 & 21.461 & 11.000 & - \\
\hline & April & 21.000 & 7.757 & 10.000 & 27.233 & 11.000 & - \\
\hline & Mei & 37.000 & 52.041 & - & - & 11.000 & - \\
\hline & Juni & 27.000 & 56.218 & - & - & 11.000 & - \\
\hline & TOTAL & 122.000 & 192.896 & 55.000 & 83.274 & 66.000 & 4.682 \\
\hline & Keterangan & \multicolumn{2}{|c|}{ Kelebihan } & \multicolumn{2}{|c|}{ Kelebihan } & \multicolumn{2}{|c|}{ Tidak Terpenuhi } \\
\hline
\end{tabular}




\begin{tabular}{|c|c|c|c|c|c|c|c|}
\hline \multirow{3}{*}{ Pabrik } & \multirow{2}{*}{ Bulan } & \multicolumn{2}{|c|}{ Phonska Subsidi } & \multicolumn{2}{|c|}{ NPK Kebomas } & \multicolumn{2}{|c|}{ Phonska plus } \\
\hline & & Target & Realisasi & Target & Realisasi & Target & Realisasi \\
\hline & Selisih & - & & & & & \\
\hline \multirow{9}{*}{$\begin{array}{c}\text { NPK } \\
\text { Phonska } \\
\text { III }\end{array}$} & Januari & 52.000 & 34.950 & - & 12.435 & - & - \\
\hline & Februari & 47.000 & 47.620 & - & - & - & - \\
\hline & Maret & 52.000 & 52.450 & - & - & - & - \\
\hline & April & 50.000 & 44.184 & - & - & - & - \\
\hline & Mei & 52.000 & 56.005 & - & - & - & - \\
\hline & Juni & 50.000 & 51.260 & - & - & - & - \\
\hline & TOTAL & 303.000 & 286.469 & 0 & 12.435 & - & - \\
\hline & Keterangan & \multicolumn{2}{|c|}{ Tidak Terpenuhi } & \multicolumn{2}{|c|}{ Kelebihan } & \multicolumn{2}{|c|}{ - } \\
\hline & Selisih & & & & & & \\
\hline
\end{tabular}

(Sumber : PT. Petrokimia Gresik)

\section{TI NJAUAN PUSTAKA}

\section{a. Definisi Sistem Produksi}

Sistem Produksi merupakan kumpulan dari sub sistem yang saling berinteraksi dengan tujuan menstranformasi input produksi menjadi output produksi. Input produksi ini dapat berupa bahan baku, mesin, tenaga kerja, modal dan informasi. Sedangkan output produksi merupakan produk produk yang dihasilkan berikut hasil sampingannya seperti limbah, informasi dan sebagainya.

\section{b. Definisi Peramalan}

Peramalan adalah proses untuk memperkirakan beberapa kebutuhan dimasa datang yang meliputi kebutuhan dalam ukuran kuantitas, kualitas, waktu dan lokasi yang dibutuhkan dalam rangka memenuhi permintaan barang ataupun jasa. Dalam hubungannya dengan horizon waktu peramalan, maka peramalan dapat diklasifikasikan ke dalam 3 kelompok (Prasetyawan,2008) :

1) Peramalan Jangka panjang, umumnya 2 sampai 10 tahun. Peramalan ini digunakan untuk perencanaan produk dan perencanaan sumber daya.

2) Peramalan Jangka Menengah, umumnya 1-24 bulan. Peramalan ini lebih mengkhusus dibandingkan peramalan jangka panjang, biasanya digunakan untuk menentukan aliran 
kas, perencanaan produksi, dan penentuan anggaran.

3) Peramalan Jangka Pendek, umumnya 1-5 minggu. Peramalan ini digunakan untuk mengambil keputusan dalam hal perlu tidaknya lembur, penjadwalan kerja, dll keputusan control jangka pendek.

\section{c. Linier Goal Programming}

Mulyono (2014) menjelaskan bahwa Linier Goal Programming (LGP) merupakan pengembangan Linier Programming (LP). LGP diperkenalkan oleh Charnes dan Cooper pada awal tahun enampuluhan.Teknik ini disempurnakan dan diperluas oleh Ijiri pada pertengahan tahun enampuluhan, dan penjelasan yang lengkap dengan beberapa aplikasi dikembangkan oleh Ognizio dan Lee pada tahun tujuhpuluhan. Perbedaan utama antara LGP dan LP terletak pada struktur dan penggunaan fungsi tujuan. Dalam LP fungsi tujuannya hanya mengandung satu tujuan, sementara dalam LGP semua tujuan apakah satu atau beberapa digabungkan dalam sebuah fungsi tujuan. Ini dapat dilakukan dengan mengekspresikan tujuan itu dalam bentuk sebuah kendala (goal Constraint), memasukkan suatu variabel simpangan (Deviation variabel) dalam kendala itu untuk mencerminkan seberapa jauh tujuan itu dicapai, dan menggabungkan variabel simpangan dalam fungsi tujuan. Dalam LP tujuannya bisa memaksimasi atau meminimasi, sementara dalam LGP tujuannya adalah meminimumkan penyimpangan-penyimpangan dari tujuan-tujuan tertentu. Ini berarti semua masalah LGP adalah masalah minimasi.

Tabel 1.2 Jenis-jenis kendala tujuan

\begin{tabular}{|c|c|c|c|}
\hline Kendala tujuan & $\begin{array}{c}\text { Variabel } \\
\text { simpang } \\
\text { an }\end{array}$ & $\begin{array}{l}\text { Kemungkin } \\
\text { an } \\
\text { simpangan }\end{array}$ & $\begin{array}{c}\text { nilai RHS } \\
\text { yang } \\
\text { diinginkan }\end{array}$ \\
\hline$a_{i j}+d_{i}=b_{i}$ & $\mathrm{~d}_{\mathrm{i}}^{-}$ & Negatif & $=\mathrm{b}_{\mathrm{i}}$ \\
\hline$a_{i j x j}+d_{i}^{\prime}=b_{i}$ & $\mathrm{~d}_{\mathrm{i}}^{+}$ & Positif & $=b_{i}$ \\
\hline$a_{i j x j}+d_{i}-d_{i}=b_{i}$ & $\mathrm{~d}_{\mathrm{i}}$ & $\begin{array}{c}\text { Negatif dan } \\
\text { positif }\end{array}$ & $\begin{array}{c}\mathrm{b}_{\mathrm{i}} \text { atau } \\
\text { lebih }\end{array}$ \\
\hline$a_{i j x j}+d_{i}-d_{i}^{\prime}=b_{i}^{b}$ & $\mathrm{~d}_{\mathrm{i}}^{-}$ & $\begin{array}{c}\text { Negatif dan } \\
\text { positif }\end{array}$ & $\begin{array}{c}\mathrm{b}_{\mathrm{i}} \text { atau } \\
\text { lebih }\end{array}$ \\
\hline$a_{i j x j}+d_{i}-d_{i}^{\prime}=b_{i}$ & $\begin{array}{c}\mathrm{d}_{\mathrm{i}} \text { dan } \\
\mathrm{d}_{\mathrm{i}}{ }^{+}\end{array}$ & $\begin{array}{c}\text { Negatif dan } \\
\text { positif }\end{array}$ & $=b_{i}$ \\
\hline$a_{i j}-d_{i}=b_{i}$ & $\mathrm{~d}_{\mathrm{i}}(\operatorname{artf})$ & Tidak ada & Pas $=b_{i}$ \\
\hline
\end{tabular}

(Sumber : Mulyono, 2014)

\section{d. LINGO}

Program LINGO berfungsi untuk memecahkan masalah optimasi nonlinier untuk mendapatkan solusi yang optimal. Model optimasi ini dibentuk berdasarkan parameter dan variabel yang nantinya digunakan memecahkan masalah optimasi. Data yang digunakan untuk model ini merupakan data numeric yang diinputkan pada model. (Indrawati,dkk, 2017) 


\section{METODOLOGI}

Dalam hal ini perlu adanya suatu kerangka pemecah masalah yang menjelaskan langkah-langkah yang digunakan untuk memecahkan suatu masalah, Langkah-langkah penelitian dan pengolahan data dapat dilihat pada flowchart gambar 1.

Gambar 6. Flowchart metodologi penelitian

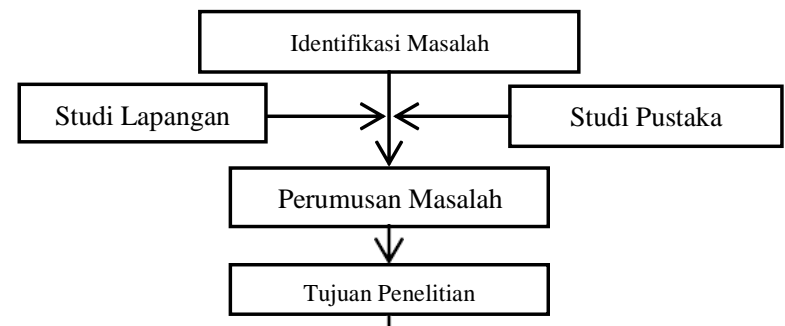
$\downarrow$

Pengumpulan Data :

1. Data realisasi produksi pada Pabrik NPK Phonska I,II \& III

2. Data Jam kerja Mesin pada Pabrik NPK Phonska I,II \& III

3. Data Consumption Rate\& ketersediaan Bahan baku utama pupuk Phonska subsidi, NPK kebomas dan Phonska Plus

4. Data Kapasitas Produksi Pabrik NPK Phonska I,II \& III

\section{$\vee$}

Pengolahan Data :

1. Melakukan peramalan target produksi pabrik NPK Phonska I,II \& III pada periode Januari-Desember 2019

a. Menganalisis data masa lalu

b. Menentukan metode peramalan yang dipergunakan.

c. Meramalkan data pada periode Januari - Desember 2019

2. Membuat model goal programming

a. Penentuan variabel keputusan

b. Penentuan fungsi kendala

c. Penentuan fungsi tujuan

d. Penentuan prioritas/bobot

e. Penentuan fungsi pencapaian

3. Melakukan penyelesaian model dengan menggunakan Lingo
4. HASIL DAN PEMBAHASAN

\subsection{Data Realisasi Produksi}

Realisasi produksi adalah data realita hasil produksi yang bisa dihasilkan oleh perusahaan pada waktu tertentu. Realisasi produksi di Pabrik NPK Phonska I,II dan III PT. Petrokimia Gresik ini di peroleh dari Laporan perusahaan di Departemen Produksi II

A. Data Realisasi produksi Produk Phonska Subsidi di departemen Produksi II A pada periode Januari 2017Desember 2018 dapat dilihat pada tabel 4.1.

Tabel 4.1 Data Realisasi Produksi produk Phonska Subsidi di departemen produksi II A pada periode Januari-Juni 2018

\begin{tabular}{|l|c|c|}
\hline \multicolumn{1}{|c|}{ Periode } & $\begin{array}{c}\text { Tahun 2017 } \\
\text { (Ton) }\end{array}$ & $\begin{array}{c}\text { Tahun 2018 } \\
\text { (Ton) }\end{array}$ \\
\hline Januari & 110.022 & 87.982 \\
\hline Februari & 83.643 & 135.058 \\
\hline Maret & 146.468 & 89.570 \\
\hline April & 100.348 & 83.760 \\
\hline Mei & 148.417 & 150.502 \\
\hline Juni & 137.775 & 137.917 \\
\hline Juli & 154.662 & 154.034 \\
\hline Agustus & 127.376 & 132.090 \\
\hline September & 83.748 & 79.034 \\
\hline Oktober & 20.982 & 18.908 \\
\hline November & 118.415 & 93.023 \\
\hline Desember & 90.095 & \\
\hline
\end{tabular}

(Sumber : PT. Petrokimia Gresik) 
Data Realisasi produksi Produk NPK Kebomas di departemen Produksi II A pada tahun Januari 2014-November 2018 dapat dilihat pada tabel 4.2

Tabel 4.2 Data Realisasi Produksi produk NPK Kebomas di departemen produksi II A pada tahun 2014-2018

\section{(Ton)}

\begin{tabular}{|l|c|c|c|c|c|}
\hline Periode & $\mathbf{2 0 1 4}$ & $\mathbf{2 0 1 5}$ & $\mathbf{2 0 1 6}$ & $\mathbf{2 0 1 7}$ & $\mathbf{2 0 1 8}$ \\
\hline Januari & 33.021 & 31.024 & 34.580 & 32.875 & 32.875 \\
\hline Februari & 18.908 & 20.381 & 20.256 & 19.848 & 20318 \\
\hline Maret & 6.709 & 35.876 & 5.603 & 4.092 & 21.461 \\
\hline April & 18.765 & 29.908 & 9.897 & 15.815 & 27.233 \\
\hline Mei & 0 & 0 & 0 & 0 & 0 \\
\hline Juni & 0 & 0 & 0 & 0 & 0 \\
\hline Juli & 0 & 0 & 0 & 0 & 0 \\
\hline Agustus & 0 & 0 & 0 & 0 & 0 \\
\hline September & 25.508 & 9.089 & 23.022 & 25.554 & 8.509 \\
\hline Oktober & 5.067 & 4.023 & 39.042 & 37.773 & 5.076 \\
\hline November & 4.989 & 4.087 & 8.866 & 8.500 & 4.986 \\
\hline Desember & 0 & 0 & 0 & 0 & 0 \\
\hline
\end{tabular}

(Sumber : PT. Petrokimia Gresik)

Phonska Plus adalah produk yang baru di launching pada tanggal 5 januari 2016. Data Realisasi produksi Produk Phonska Plus di departemen Produksi II A pada tahun Januari 2016- November 2018 dapat dilihat pada tabel 4.3

Tabel 4.3 Data Realisasi Produksi produk Phonska Plus di departemen produksi II A pada tahun 2016-2018

\section{(Ton)}

\begin{tabular}{|l|c|c|c|}
\hline \multicolumn{1}{|c|}{ Periode } & $\mathbf{2 0 1 6}$ & $\mathbf{2 0 1 7}$ & $\mathbf{2 0 1 8}$ \\
\hline Januari & 7.023 & 7.759 & 4.682 \\
\hline Februari & 17.378 & 14.358 & 15.868 \\
\hline Maret & 0 & 0 & 0 \\
\hline
\end{tabular}

\begin{tabular}{|l|c|c|c|}
\hline \multicolumn{1}{|c|}{ Periode } & $\mathbf{2 0 1 6}$ & $\mathbf{2 0 1 7}$ & $\mathbf{2 0 1 8}$ \\
\hline April & 0 & 0 & 0 \\
\hline Mei & 0 & 0 & 0 \\
\hline Juni & 15.987 & 9.340 & 12.663 \\
\hline Juli & 0 & 0 & 0 \\
\hline Agustus & 33.023 & 26.154 & 20.956 \\
\hline September & 0 & 0 & 0 \\
\hline Oktober & 0 & 0 & 0 \\
\hline November & 0 & 0 & 0 \\
\hline Desember & 4.601 & 24.364 & 0 \\
\hline
\end{tabular}

(Sumber : PT. Petrokimia Gresik)

\subsection{Data Ketersediaan Hari Kerja}

\section{Mesin}

Pada Pabrik NPK Phonska I,II dan III Departemen Produksi II A PT. Petrokimia Gresik ini memiliki keterbatasan dalam ketersediaan hari kerja mesin /Stream Days yang dimiliki pada setiap bulannya. Hal tersebut terjadi karena adanya alokasi Downtime Unschedule dan Downtime Schedule seperti :

1. Unschedule $(U n s)=1$ hari.

2. Schedule Shutdown $(\mathrm{SD})$ bulanan $=3$ hari

3. Schedule Cleaning (memproduksi dengan formula yang berbeda untuk pabrik NPK Phonska II ) $=0,5$ hari

4. Shutdown tahunan pada bulan oktober $=25$ hari

Ketersediaan hari kerja mesin pada masing-masing produk di Pabrik 
NPK Phonska I pada periode Januari-

Desember 2019 dapat dilihat pada tabel 4.4 .

Tabel 4.4 Ketersediaan hari kerja mesin/Stream Days (Hari) di Pabrik NPK Phonska I (Hari)

\begin{tabular}{|c|c|c|c|c|c|}
\hline \multirow{2}{*}{$\begin{array}{c}\text { Pabrik NPK } \\
\text { Phonska I }\end{array}$} & \multirow{2}{*}{$\begin{array}{l}\text { Total } \\
\text { Hari }\end{array}$} & \multicolumn{3}{|c|}{ Downtime (Hari) } & \multirow{2}{*}{$\begin{array}{c}\text { Stream } \\
\text { Days } \\
\text { (Hari) }\end{array}$} \\
\hline & & $\begin{array}{c}\text { Unsche } \\
\text { dule }\end{array}$ & $\begin{array}{l}\text { Bulan } \\
\text { an }\end{array}$ & Tahunan & \\
\hline Januari & 31 & 1 & 3 & 0 & 27 \\
\hline Februari & 28 & 1 & 3 & 0 & 24 \\
\hline Maret & 31 & 1 & 3 & 0 & 27 \\
\hline April & 30 & 1 & 3 & 0 & 26 \\
\hline Mei & 31 & 1 & 3 & 0 & 27 \\
\hline Juni & 30 & 1 & 3 & 0 & 26 \\
\hline Juli & 31 & 1 & 3 & 0 & 27 \\
\hline Agustus & 31 & 1 & 3 & 0 & 27 \\
\hline September & 30 & 1 & 3 & 0 & 26 \\
\hline Oktober & 31 & 1 & 0 & 25 & 5 \\
\hline November & 30 & 1 & 3 & 0 & 26 \\
\hline Desember & 31 & 1 & 3 & 0 & 27 \\
\hline
\end{tabular}

(Sumber : PT. Petrokimia Gresik)

Ketersediaan hari kerja mesin pada masing-masing produk di Pabrik NPK Phonska II pada periode JanuariDesember 2019 dapat dilihat pada tabel 4.5.

Tabel 4.5 Ketersediaan hari kerja mesin/Stream Days (Hari) di Pabrik NPK Phonska II

\begin{tabular}{|c|c|c|c|c|c|c|}
\hline \multirow{2}{*}{$\begin{array}{c}\text { Pabrik } \\
\text { NPK } \\
\text { Phonska } \\
\text { II }\end{array}$} & \multirow{2}{*}{$\begin{array}{l}\text { Total } \\
\text { Hari }\end{array}$} & \multicolumn{4}{|c|}{ Downtime (Hari) } & \multirow{2}{*}{$\begin{array}{c}\text { Strea } \\
m \\
\text { Days } \\
\text { (Hari } \\
\text { ) }\end{array}$} \\
\hline & & $\begin{array}{l}\text { Unsc } \\
\text { hedu } \\
\text { le }\end{array}$ & $\begin{array}{c}\text { SD } \\
\text { Bulan } \\
\text { an }\end{array}$ & $\begin{array}{c}\text { SD } \\
\text { Tahun } \\
\text { an }\end{array}$ & $\begin{array}{l}\text { Clea } \\
\text { ning }\end{array}$ & \\
\hline Januari & 31 & 1 & 3 & 0 & 0,5 & 26,5 \\
\hline Februari & 28 & 1 & 3 & 0 & 0,5 & 23,5 \\
\hline Maret & 31 & 1 & 3 & 0 & 0,5 & 26,5 \\
\hline April & 30 & 1 & 3 & 0 & 0,5 & 25,5 \\
\hline
\end{tabular}

\begin{tabular}{|c|c|c|c|c|c|c|}
\hline \multirow{2}{*}{$\begin{array}{c}\text { Pabrik } \\
\text { NPK } \\
\text { Phonska } \\
\text { II }\end{array}$} & \multirow{2}{*}{$\begin{array}{l}\text { Total } \\
\text { Hari }\end{array}$} & \multicolumn{4}{|c|}{ Downtime (Hari) } & \multirow{2}{*}{$\begin{array}{c}\text { Strea } \\
m \\
\text { Days } \\
\text { (Hari } \\
\text { ) }\end{array}$} \\
\hline & & $\begin{array}{l}\text { Unsc } \\
\text { hedu } \\
\text { le }\end{array}$ & $\begin{array}{c}\text { SD } \\
\text { Bulan } \\
\text { an }\end{array}$ & $\begin{array}{c}\text { SD } \\
\text { Tahun } \\
\text { an }\end{array}$ & $\begin{array}{l}\text { Clea } \\
\text { ning }\end{array}$ & \\
\hline Mei & 31 & 1 & 3 & 0 & 0,5 & 26,5 \\
\hline Juni & 30 & 1 & 3 & 0 & 0,5 & 25,5 \\
\hline Juli & 31 & 1 & 3 & 0 & 0,5 & 26,5 \\
\hline Agustus & 31 & 1 & 3 & 0 & 0,5 & 26,5 \\
\hline September & 30 & 1 & 3 & 0 & 0,5 & 25,5 \\
\hline Oktober & 31 & 1 & 0 & 25 & 0,5 & 4,5 \\
\hline November & 30 & 1 & 3 & 0 & 0,5 & 25,5 \\
\hline Desember & 31 & 1 & 3 & 0 & 0,5 & 26,5 \\
\hline
\end{tabular}

(Sumber : PT. Petrokimia Gresik)

Ketersediaan hari kerja mesin pada masing-masing produk di Pabrik NPK Phonska III pada periode JanuariDesember 2019 dapat dilihat pada tabel 4.6.

Tabel 4.6 Ketersediaan hari kerja mesin/Stream Days (Hari) di Pabrik NPK Phonska III

\begin{tabular}{|c|c|c|c|c|c|}
\hline \multirow{2}{*}{$\begin{array}{c}\text { Pabrik } \\
\text { NPK } \\
\text { Phonska III }\end{array}$} & \multirow{2}{*}{$\begin{array}{l}\text { Total } \\
\text { Hari }\end{array}$} & \multicolumn{3}{|c|}{ Downtime (Hari) } & \multirow{2}{*}{$\begin{array}{c}\text { Stream } \\
\text { Days (Hari) }\end{array}$} \\
\hline & & $\begin{array}{c}\text { Unsche } \\
\text { dule }\end{array}$ & $\begin{array}{c}\text { SD } \\
\text { Bulana } \\
\mathrm{n}\end{array}$ & $\begin{array}{c}\text { SD } \\
\text { Tahu } \\
\text { nan }\end{array}$ & \\
\hline Januari & 31 & 1 & 3 & 0 & 27 \\
\hline Februari & 28 & 1 & 3 & 0 & 24 \\
\hline Maret & 31 & 1 & 3 & 0 & 27 \\
\hline April & 30 & 1 & 3 & 0 & 26 \\
\hline Mei & 31 & 1 & 3 & 0 & 27 \\
\hline Juni & 30 & 1 & 3 & 0 & 26 \\
\hline Juli & 31 & 1 & 3 & 0 & 27 \\
\hline Agustus & 31 & 1 & 3 & 0 & 27 \\
\hline September & 30 & 1 & 3 & 0 & 26 \\
\hline Oktober & 31 & 1 & 0 & 25 & 5 \\
\hline November & 30 & 1 & 3 & 0 & 26 \\
\hline Desember & 31 & 1 & 3 & 0 & 27 \\
\hline
\end{tabular}

(Sumber : PT. Petrokimia Gresik) 
4.3 Data Consumption Rate Bahan Baku

Pupuk yang di produksi di PT. Petrokimia Gresik memiliki kebutuhan bahan baku (Consumption rate) yang berbeda-beda. Bahan baku utama pada produk pupuk Phonska Subsidi, NPK Kebomas dan Phonska Plus di PT. Petrokimia Gresik adalah $\mathrm{H}_{2} \mathrm{SO}$ dengan konsentrasi $98,5 \%, \mathrm{H}_{3} \mathrm{PO}_{4} \mathrm{P}_{2} \mathrm{O}_{5}$ dengan konsentrasi $54 \%, \mathrm{NH}_{3}$, Urea, KCL dan ZA. Consumption Rate pada masingmasing produk dapat dilihat pada tabel 4.7.

Tabel 4.7 Data Consumption

Rate pupuk phonska subsidi, NPK

kebomas dan Phonska plus

\begin{tabular}{|l|c|c|c|c|c|c|c|}
\hline \multirow{2}{*}{ Produk } & \multicolumn{7}{|c|}{ Consumption Rate (Ton/1Ton produk) } \\
\cline { 2 - 8 } & $\mathrm{H}_{2} \mathrm{SO}_{4}$ & $\begin{array}{c}\mathrm{H}_{3} \mathrm{PO}_{4} \\
\mathrm{P}_{2} \mathrm{O}_{5}\end{array}$ & $\mathrm{NH}_{3}$ & Urea & $\mathrm{KCL}$ & $\mathrm{ZA}$ & $\begin{array}{c}\text { Total } \\
\text { (Ton/1 } \\
\text { Ton } \\
\text { Produk) }\end{array}$ \\
\hline $\begin{array}{l}\text { Phon } \\
\text { ska }\end{array}$ & 0,21 & 0,28 & 0,1380 & 0,02 & 0,26 & 0,14 & 1,06 \\
Subs & 70 & 50 & 00 & 00 & 00 & \\
idi & 0,21 & 0,28 & 0,1380 & 0,02 & 0,26 & 0,14 & 1,06 \\
\hline $\begin{array}{l}\text { NPK } \\
\text { Kebo }\end{array}$ & 70 & 50 & & 00 & 00 & 00 & \\
\hline $\begin{array}{l}\text { Phon } \\
\text { ska } \\
\text { Plus }\end{array}$ & 0,20 & 0,28 & 0,1373 & 0,03 & 0,26 & 0,12 & 1,0376 \\
\hline
\end{tabular}

(Sumber : PT. Petrokimia Gresik)

Untuk bahan baku dibatasi oleh perusahaan yaitu dengan ketersediaan bahan baku di pabrik NPK Phonska I dan masing-masing produk setiap tahunnya dapat dilihat pada tabel 4.8

Tabel 4.8 Keterbatasan bahan baku di pabrik NPK Phonska I

\begin{tabular}{|c|c|c|c|c|c|c|}
\hline \multirow{2}{*}{\begin{tabular}{c} 
Produk \\
\cline { 2 - 7 }
\end{tabular}} & \multicolumn{5}{|c|}{ Ketersediaan Bahan Baku Produk pada Pabrik NPK } \\
\cline { 2 - 7 } & $\mathrm{H}_{2} \mathrm{SO}_{4}$ & $\begin{array}{c}\mathrm{H}_{3} \mathrm{PO}_{4} \\
\mathrm{P}_{2} \mathrm{O}_{5}\end{array}$ & $\mathrm{NH}_{3}$ & Urea & KCL & ZA \\
\hline $\begin{array}{c}\text { Phonska } \\
\text { subsidi }\end{array}$ & 91.358 & 119.986 & 58.098 & 8.420 & 109.460 & 58.940 \\
\hline $\begin{array}{c}\text { NPK } \\
\text { Kebomas }\end{array}$ & 42.032 & 64.630 & 28.780 & 5.468 & 45.664 & 35.102 \\
\hline $\begin{array}{c}\text { Phonska } \\
\text { Plus }\end{array}$ & 9.360 & 10.758 & 4.952 & 380 & 8.950 & 5.848 \\
\hline
\end{tabular}

(Sumber : PT. Petrokimia Gresik)

Untuk bahan baku dibatasi oleh perusahaan yaitu dengan ketersediaan bahan baku di pabrik NPK Phonska II dan masing-masing produk setiap tahunnya dapat dilihat pada tabel 4.9

Tabel 4.9 Keterbatasan bahan baku di pabrik NPK Phonska II

\begin{tabular}{|l|c|c|c|c|c|c|}
\hline \multirow{2}{*}{ Produk } & \multicolumn{5}{|c|}{ Ketersediaan bahan baku produk di pabrik NPK } \\
& \multicolumn{5}{|c|}{ Phonska II (Ton) } \\
\cline { 2 - 7 } & $\mathrm{H}_{2} \mathrm{SO}_{4}$ & $\begin{array}{c}\mathrm{H}_{3} \mathrm{PO}_{4} \\
\mathrm{P}_{2} \mathrm{O}_{5}\end{array}$ & $\mathrm{NH}_{3}$ & Urea & KCL & ZA \\
\hline $\begin{array}{l}\text { Phonska } \\
\text { subsidi }\end{array}$ & 68.355 & 89.775 & 43.470 & 6.300 & 81.900 & 44.100 \\
\hline Kebomas & 42.032 & 64.630 & 28.780 & 5.468 & 45.664 & 35.102 \\
\hline $\begin{array}{l}\text { Nhonska } \\
\text { Plus }\end{array}$ & 9.360 & 10.758 & 4.952 & 380 & 8.950 & 5.848 \\
& & & & & & \\
\hline
\end{tabular}

(Sumber : PT. Petrokimia Gresik) 
Untuk bahan baku dibatasi oleh perusahaan yaitu dengan ketersediaan bahan baku di pabrik NPK Phonska III dan masing-masing produk setiap tahunnya dapat dilihat pada tabel 4.10

Tabel 4.10 Keterbatasan bahan baku di pabrik NPK Phonska III

\begin{tabular}{|l|c|c|c|c|c|c|}
\hline \multirow{2}{*}{ Periode } & \multicolumn{5}{|c|}{ Ketersediaan Bahan Baku Produk pada Pabrik NPK Phonska } \\
& $\mathrm{H}_{2} \mathrm{SO}_{4}$ & $\begin{array}{c}\mathrm{H}_{3} \mathrm{PO}_{4} \\
\mathrm{P}_{2} \mathrm{O}_{5}\end{array}$ & $\mathrm{NH}_{3}$ & Urea & KCL & ZA \\
\hline $\begin{array}{l}\text { Phonska } \\
\text { subsidi }\end{array}$ & 128.898 & 169.290 & 81.972 & 11.880 & 154.440 & 83.160 \\
\hline $\begin{array}{l}\text { NPK } \\
\text { Kebomas }\end{array}$ & 42.032 & 64.630 & 28.780 & 5.468 & 45.664 & 35.102 \\
\hline Phonska Plus & 9.360 & 10.758 & 4.952 & 380 & 8.950 & 5.848 \\
& & & & & & \\
\hline
\end{tabular}

(Sumber : PT. Petrokimia Gresik)

\subsection{Data Kapasitas Produksi}

Dalam memproduksi pupuk Phonska Bersubsidi, NPK Kebomas dan Phonska Subsidi perusahaan menggunakan Pabrik NPK Phonska I,II dan III. Masing-masing Pabrik memiliki kapasitas produksi harian yang berbedabeda dalam memproduksi masingmasing produk pupuk. Kapasitas produksi harian masing-masing Pabrik di Departemen Produksi II A dapat dilihat pada tabel 4.11 .
Tabel 4.11 Kapasitas Produksi harian Pabrik NPK Phonska I,II dan III

\begin{tabular}{|c|c|c|c|}
\hline \multirow{2}{*}{ Produk } & \multicolumn{3}{|c|}{ Pabrik (Ton/hari) } \\
\cline { 2 - 4 } & $\begin{array}{c}\text { NPK } \\
\text { Phonska I }\end{array}$ & $\begin{array}{c}\text { NPK } \\
\text { Phonska II }\end{array}$ & $\begin{array}{c}\text { NPK } \\
\text { Phonska III }\end{array}$ \\
\hline $\begin{array}{c}\text { Phonska } \\
\text { Bersubsidi }\end{array}$ & 1.500 & 2.000 & 2.000 \\
\hline NPK Kebomas & 1.200 & 1.500 & 1.500 \\
\hline Phonska Plus & 1.050 & 1.400 & 1.350 \\
\hline
\end{tabular}

(Sumber : PT. Petrokimia Gresik)

\subsection{Peramalan Target Produksi}

Metode Time Series yang digunakan dalam peramalan produk phonska subsidi adalah metode winter's dengan menggunakan model multiplicative dan additive dengan menggunakan program Minitab. Pada tabel 4.12 Hasil peramalan pada produk Phonska Subsidi.

Tabel 4.12 Hasil peramalan pada Produk Phonska Plus

\begin{tabular}{|c|c|}
\hline Periode & Hasil Peramalan (Ton) \\
\hline 1 & 89701 \\
\hline 2 & 102508 \\
\hline 3 & 108270 \\
\hline 4 & 84886 \\
\hline 5 & 143347 \\
\hline 6 & 131893 \\
\hline 7 & 148621 \\
\hline 8 & 124386 \\
\hline 9 & 76011 \\
\hline 10 & 5975 \\
\hline 11 & 108591 \\
\hline 12 & 87267 \\
\hline Jumlah & 1211456 \\
\hline
\end{tabular}

(Sumber data diolah)

Dan untuk produk NPK Kebomas dan Phonska Plus menggunakan metode single exponential smoothing dan double 
exponential smoothing. Hasil peramalan produk NPK Kebomas dapat dilihat pada Tabel 4.13 dan untuk hasil peramalan pada produk Phonska Plus dapat dilihat pada Tabel 4.14.

Tabel 4.13 Hasil peramalan NPK Kebomas.

\begin{tabular}{|c|c|}
\hline Periode & $\begin{array}{c}\text { Hasil Peramalan } \\
\text { (Ton) }\end{array}$ \\
\hline 1 & 0 \\
\hline 2 & 0 \\
\hline 3 & 04795,16 \\
\hline 4 & 0 \\
\hline 5 & 0 \\
\hline 6 & 0 \\
\hline 7 & 0 \\
\hline 8 & 36851,5 \\
\hline 9 & 6000 \\
\hline 10 & 38250 \\
\hline 11 & 37080,95 \\
\hline 12 & 182977,6 \\
\hline Jumlah & $0101 a \mathrm{~h})$ \\
\hline$($ Sum & 0 \\
\hline
\end{tabular}

(Sumber data diolah)

Tabel 4.14 Hasil peramalan Phonska Plus

\begin{tabular}{|c|c|}
\hline Periode & $\begin{array}{c}\text { Hasil Peramalan } \\
\text { (Ton) }\end{array}$ \\
\hline 1 & 25055,56 \\
\hline 2 & 0 \\
\hline 3 & 0 \\
\hline 4 & 0 \\
\hline 5 & 0 \\
\hline 6 & 0 \\
\hline 7 & 0 \\
\hline 8 & 0 \\
\hline 9 & 0 \\
\hline
\end{tabular}

\begin{tabular}{|c|c|}
\hline Periode & $\begin{array}{c}\text { Hasil Peramalan } \\
\text { (Ton) }\end{array}$ \\
\hline 10 & 0 \\
\hline 11 & 15572,33 \\
\hline 12 & 12944,44 \\
\hline Jumlah & 53572,33 \\
\hline
\end{tabular}

(Sumber data diolah)

\subsection{Formulasi Model Goal 1131 Programming}

'Variable keputusan yang digunakan dalam model ini adalah "Berapa jumlah produksi produk $i$ yang akan diproduksi pada pabrik “ $j "$ pada periode $t$ ". kemudian data tersebut didefinisikan sebagai berikut :

Xijt $=$ jumlah produksi produk $i$ yang akan diproduksi di pabrik $j$ pada periode waktu $t$.

$i=$ jenis produk yang akan diproduksi,

$1=$ Phonska subsidi

$2=$ NPK Kebomas

3=Phonska Plus

$j \quad=$ Unit Pabrik NPK Phonska

1= Unit Pabrik NPK Phonska I

2= Unit Pabrik NPK Phoska II

3= Unit Pabrik NPK Phonska III

$t=$ Periode produksi produk,

1 = Januari

2 = Februari

3 = Maret

4 = April

$5=$ Mei 


$$
\begin{aligned}
& 6=\text { Juni } \\
& 7=\text { Juli } \\
& 8=\text { Agustus } \\
& 9=\text { September } \\
& 10=\text { Oktober } \\
& 11=\text { November } \\
& 12=\text { Desember } \\
& \text { DNk = Deviasi Negatif } \\
& \text { DPk = Deviasi Positif } \\
& k=\text { Pembatas ke ... }
\end{aligned}
$$

\subsubsection{Merumuskan Fungsi Kendala}

Fungsi kendala dari model goal programming pada permasalahan ini adalah sebagai berikut :

a. Kendala Jumlah Tonase Target Produksi

Kendala pertama adalah Jumlah Tonase Target Produksi pada pupuk Phonska Subsidi, NPK Kebomas dan Phonska Plus. Pada kendala ini perusahaan ingin memenuhi target produksi yang sudah direncanakan. Maka persamaannya adalah sebagai berikut :

1) Phonska subsidi

$$
\begin{aligned}
& X 111+X 121+X 131+X 112+X 122 \\
& +X 132+X 113+X 123+X 133+X 11 \\
& 4+X 124+X 134+X 115+X 125+X 1 \\
& 35+X 116+X 126+X 136+X 117+X \\
& 127+X 137+X 118+X 128+X 138+ \\
& X 119+X 129+X 139+X 1110+X 12 \\
& 10+X 1310+X 1111+X 1211+X 13
\end{aligned}
$$

$$
\begin{aligned}
& 11+\mathrm{X} 1112+\mathrm{X} 1212+\mathrm{X} 1312+\mathrm{DN} 0 \\
& 1-\mathrm{DP} 01=1211456 \\
& \text { 2) }
\end{aligned}
$$

$$
\begin{aligned}
& X 211+X 221+X 231+X 212+X 222 \\
& +X 232+X 213+X 223+X 233+X 21 \\
& 4+X 224+X 234+X 215+X 225+X 2 \\
& 35+X 216+X 226+X 236+X 217+X \\
& 227+X 237+X 218+X 228+X 238+ \\
& X 219+X 229+X 239+X 2110+X 22 \\
& 10+X 2310+X 2111+X 2211+X 23 \\
& 11+X 2112+X 2212+X 2312+D N 0 \\
& 2-D P 02=182977,6
\end{aligned}
$$

3) Phonska Plus

$$
\begin{aligned}
& X 311+X 321+X 331+X 312+X 322 \\
& +X 332+X 313+X 323+X 333+X 31 \\
& 4+X 324+X 334+X 315+X 325+X 3 \\
& 35+X 316+X 326+X 336+X 317+X \\
& 327+X 337+X 318+X 328+X 338+ \\
& X 319+X 329+X 339+X 3110+X 32 \\
& 10+X 3310+X 3111+X 3211+X 33 \\
& 11+X 3112+X 3212+X 3312+D N 0 \\
& 3-D P 03=53572,33
\end{aligned}
$$

b. Kendala Ketersediaan Hari kerja Mesin.

Kendala kedua adalah ketersediaan Hari kerja Mesin, Pembatas ini bertujuan untuk membatasi jumlah hari kerja mesin yang tersedia pada masing-masing pabrik untuk memproduksi produk Phonska Subsidi, NPK Kebomas dan Phonska Plus di setiap 
bulannya. Maka Persamaannya adalah sebagai berikut :

1) Pabrik NPK Phonska I

$\mathrm{X} 111 / 1500+\mathrm{X} 211 / 1200+\mathrm{X} 311 / 1050+$ DN04 - DP04 = 27;

$\mathrm{X} 112 / 1500+\mathrm{X} 212 / 1200+\mathrm{X} 312 / 1050+$ DN05 - DP05 = 24;

$$
\mathrm{X} 113 / 1500+\mathrm{X} 213 / 1200+\mathrm{X} 313 / 1050+
$$$$
\text { DN06 - DP06 = 27; }
$$

$\mathrm{X} 114 / 1500+\mathrm{X} 214 / 1200+\mathrm{X} 314 / 1050+$ DN07 - DP07 = 26;

$\mathrm{X} 115 / 1500+\mathrm{X} 215 / 1200+\mathrm{X} 315 / 1050+$

DN08 - DP08 = 27;

$\mathrm{X} 116 / 1500+\mathrm{X} 216 / 1200+\mathrm{X} 316 / 1050+$ DN09 - DP09 = 26;

$\mathrm{X} 117 / 1500+\mathrm{X} 217 / 1200+\mathrm{X} 317 / 1050+$ DN10 - DP10 = 27;

$\mathrm{X} 118 / 1500+\mathrm{X} 218 / 1200+\mathrm{X} 318 / 1050+$

DN11 - DP11 = 27;

$\mathrm{X} 119 / 1500+\mathrm{X} 219 / 1200+\mathrm{X} 319 / 1050+$

DN12 - DP12 = 26;

$\mathrm{X} 1110 / 1500+\mathrm{X} 2110 / 1200+$

$\mathrm{X} 3110 / 1050+\mathrm{DN} 13-\mathrm{DP} 13=5$;

$\mathrm{X} 1111 / 1500+\mathrm{X} 2111 / 1200+$

$\mathrm{X} 3110 / 1050$ + DN14 - DP14 = 26;

$\mathrm{X} 1112 / 1500+\mathrm{X} 2112 / 1200+$

$\mathrm{X} 3112 / 1050$ + DN15 - DP15 = 27;

2) Pabrik NPK Phonska II

$\mathrm{X} 121 / 2000+\mathrm{X} 221 / 1500+\mathrm{X} 321 / 1400+$

DN16 - DP16 = 26.5;

$\mathrm{X} 122 / 2000+\mathrm{X} 222 / 1500+\mathrm{X} 322 / 1400+$ DN17 - DP17 = 23.5;
$\mathrm{X} 123 / 2000+\mathrm{X} 223 / 1500+\mathrm{X} 323 / 1400+$

DN18 - DP18 = 26.5;

$\mathrm{X} 124 / 2000+\mathrm{X} 224 / 1500+\mathrm{X} 324 / 1400+$

DN19 - DP19 = 25.5;

$\mathrm{X} 125 / 2000+\mathrm{X} 225 / 1500+\mathrm{X} 325 / 1400+$

DN20 - DP20 = 26.5;

$\mathrm{X} 126 / 2000+\mathrm{X} 226 / 1500+\mathrm{X} 326 / 1400+$

DN21 - DP21 = 25.5;

$\mathrm{X} 127 / 2000+\mathrm{X} 227 / 1500+\mathrm{X} 327 / 1400+$

DN22 - DP22 = 26.5;

$\mathrm{X} 128 / 2000+\mathrm{X} 228 / 1500+\mathrm{X} 328 / 1400+$

DN23 - DP23 = 26.5;

$\mathrm{X} 129 / 2000+\mathrm{X} 229 / 1500+\mathrm{X} 329 / 1400+$

DN24 - DP24 = 25.5;

$\mathrm{X} 1210 / 2000+\mathrm{X} 2210 / 1500+$

$\mathrm{X} 3210 / 1400+\mathrm{DN} 25-\mathrm{DP} 25=4.5$;

$\mathrm{X} 1211 / 2000+\mathrm{X} 2211 / 1500+$

$\mathrm{X} 3211 / 1400+\mathrm{DN} 26-\mathrm{DP} 26=25.5$;

$\mathrm{X} 1212 / 2000+\mathrm{X} 2212 / 1500+$

$\mathrm{X} 3212 / 1400+\mathrm{DN} 27-\mathrm{DP} 27=26.5$;

3) Pabrik NPK Phonska III

$\mathrm{X} 131 / 2000+\mathrm{X} 231 / 1500+\mathrm{X} 331 / 1350+$

DN28 - DP28 = 27;

$\mathrm{X} 132 / 2000+\mathrm{X} 232 / 1500+\mathrm{X} 332 / 1350+$

DN29 - DP29 = 24;

$\mathrm{X} 133 / 2000+\mathrm{X} 233 / 1500+\mathrm{X} 333 / 1350+$

DN30 - DP30 = 27;

$\mathrm{X} 134 / 2000+\mathrm{X} 234 / 1500+\mathrm{X} 334 / 1350+$ DN31 - DP31 = 26;

$\mathrm{X} 135 / 2000+\mathrm{X} 235 / 1500+\mathrm{X} 335 / 1350+$

DN32 - DP32 = 27; 
$\mathrm{X} 136 / 2000+\mathrm{X} 236 / 1500+\mathrm{X} 336 / 1350+$

DN33 - DP33 = 26;

$\mathrm{X} 137 / 2000+\mathrm{X} 237 / 1500+\mathrm{X} 337 / 1350+$

DN34 - DP34 = 27;

$\mathrm{X} 138 / 2000+\mathrm{X} 238 / 1500+\mathrm{X} 338 / 1350+$

DN35 - DP35 = 27;

$\mathrm{X} 139 / 2000+\mathrm{X} 239 / 1500+\mathrm{X} 339 / 1350+$

DN36 - DP36 = 26;

$\mathrm{X} 1310 / 2000+\mathrm{X} 2310 / 1500+$

$\mathrm{X} 3310 / 1350+\mathrm{DN} 37-\mathrm{DP} 37=5$;

$\mathrm{X} 1311 / 2000+\mathrm{X} 2311 / 1500+$

$\mathrm{X} 3311 / 1350+\mathrm{DN} 38-\mathrm{DP} 38=26$;

$\mathrm{X} 1312 / 2000+\mathrm{X} 2312 / 1500+$

$\mathrm{X} 3312 / 1350+\mathrm{DN} 39-\mathrm{DP} 39=27 ;$

c. Kendala Bahan Baku yang Digunakan

Kendala ketiga adalah ketersediaan bahan baku yang digunakan, pembatas ini bertujuan untuk membatasi pemborosan bahan baku sehingga dapat sesuai dengan jumlah pemakaian yang ditetapkan oleh perusahaan. Bahan baku utama yang digunakan yaitu Asam sulfat, Asam Fosfat, Amoniak, Urea, KCL dan ZA.

1) Bahan Baku Asam Sulfat $\left(\mathrm{H}_{2} \mathrm{SO}_{4}\right)$

- Phonska Subsidi pada Pabrik NPK Phonska I

$0.217 * \mathrm{X} 111+0.217 * \mathrm{X} 112+0.217 * \mathrm{X}$ $113+0.217 * \mathrm{X} 114+0.217 * \mathrm{X} 115+0.2$ $17 * \mathrm{X} 116+0.217 * \mathrm{X} 117+0.217 * \mathrm{X} 11$
$8+0.217 * \mathrm{X} 119+0.217 * \mathrm{X} 1110+$ $0.217 * \mathrm{X} 1111+0.217 * \mathrm{X} 1112+$ DN40 - DP40 = 91358;

- NPK Kebomas pada Pabrik NPK Phonska I

$0.2003 * \mathrm{X} 211+0.2003 * \mathrm{X} 212+$ $0.2003 * \mathrm{X} 213+0.2003 * \mathrm{X} 214+$ $0.2003 * \mathrm{X} 215+0.2003 * \mathrm{X} 216+$ $0.2003 * \mathrm{X} 217+0.2003 * \mathrm{X} 218+$ $0.2003 * X 219+0.2003 * X 2110+$ $0.2003 * \mathrm{X} 2111+0.2003 * \mathrm{X} 2112+$ DN41- DP41 $=42032$

- Phonska Plus pada Pabrik NPK Phonska I

$0.217 * \mathrm{X} 311+0.217 * \mathrm{X} 312+$ $0.217 * \mathrm{X} 313+0.217 * \mathrm{X} 314+$ $0.217 * \mathrm{X} 315+0.217 * \mathrm{X} 316+$ $0.217 * \mathrm{X} 317+0.217 * \mathrm{X} 318+$ $0.217 * \mathrm{X} 319+0.217 * \mathrm{X} 3110+$ $0.217 * \mathrm{X} 3111+0.217 * \mathrm{X} 3112+$ DN42 -DP42 = 9360;

- Phonska Subsidi pada Pabrik NPK Phonska II

$0.217 * \mathrm{X} 121+0.217 * \mathrm{X} 122+$ $0.217 * \mathrm{X} 123+0.217 * \mathrm{X} 124+$ $0.217 * \mathrm{X} 125+0.217 * \mathrm{X} 126+$ $0.217 * \mathrm{X} 127+0.217 * \mathrm{X} 128+$ $0.217 * \mathrm{X} 129+0.217 * \mathrm{X} 1210+0.5+$ $0.217 * \mathrm{X} 1211+0.217 * \mathrm{X} 1212$ +DN43 - DP43 = 68355;

- NPK Kebomas pada Pabrik NPK Phonska II 


$$
\begin{aligned}
& 0.2003 * \mathrm{X} 221+0.2003 * \mathrm{X} 222+ \\
& 0.2003 * \mathrm{X} 223+0.2003 * \mathrm{X} 224+ \\
& 0.2003 * \mathrm{X} 225+0.2003 * \mathrm{X} 226 \\
& +0.2003 * \mathrm{X} 227+0.2003 * \mathrm{X} 228+ \\
& 0.2003 * \mathrm{X} 229+0.2003 * \mathrm{X} 2210+ \\
& 0.2003 * \mathrm{X} 2211+0.2003 * \mathrm{X} 2212+ \\
& \mathrm{DN} 44-\mathrm{DP} 44=42032
\end{aligned}
$$

- Phonska Plus pada Pabrik NPK

Phonska II

$0.217 * \mathrm{X} 321+0.217 * \mathrm{X} 322+$

$0.217 * \mathrm{X} 323+0.217 * \mathrm{X} 324+$

$0.217 * \mathrm{X} 325+0.217 * \mathrm{X} 326$

$+0.217 * \mathrm{X} 327+0.217 * \mathrm{X} 328+$

$0.217 * \mathrm{X} 329+0.217 * \mathrm{X} 3210+$

$0.217 * \mathrm{X} 3211+0.217 * \mathrm{X} 3212+$

DN45 - DP45 = 9360;

- Phonska Subsidi pada Pabrik NPK

Phonska III

$0.217 * \mathrm{X} 131+0.217 * \mathrm{X} 132+$

$0.217 * \mathrm{X} 133+0.217 * \mathrm{X} 134+$

$0.217 * \mathrm{X} 135+0.217 * \mathrm{X} 136$

$+0.217 * \mathrm{X} 137+0.217 * \mathrm{X} 138+$

$0.217 * X 139+0.217 * \mathrm{X} 1310+$

$0.217 * \mathrm{X} 1311+0.217 * \mathrm{X} 1312+$

DN46 - DP46 = 128898;

- NPK Kebomas pada Pabrik NPK

Phonska III

$$
\begin{aligned}
& 0.2003 * \mathrm{X} 231+0.2003 * \mathrm{X} 232+ \\
& 0.2003 * \mathrm{X} 233+0.2003 * \mathrm{X} 234+ \\
& 0.2003 * \mathrm{X} 235+0.2003 * \mathrm{X} 236 \\
& +0.2003 * \mathrm{X} 237+0.2003 * \mathrm{X} 238+ \\
& 0.2003 * \mathrm{X} 239+0.2003 * \mathrm{X} 2310+
\end{aligned}
$$

$0.2003 * X 2311+0.2003 * X 2312+$

DN47 - DP47 = 42032;

- Phonska Plus pada Pabrik NPK Phonska III

$$
\begin{aligned}
& 0.217 * \mathrm{X} 331+0.217 * \mathrm{X} 332+ \\
& 0.217 * \mathrm{X} 333+0.217 * \mathrm{X} 334+ \\
& 0.217 * \mathrm{X} 335+0.217 * \mathrm{X} 336 \\
& +0.217 * \mathrm{X} 337+0.217 * \mathrm{X} 338+ \\
& 0.217 * \mathrm{X} 339+0.217 * \mathrm{X} 3310+ \\
& 0.217 * \mathrm{X} 3311+0.217 * \mathrm{X} 3312+ \\
& \mathrm{DN} 48-\mathrm{DP} 48=9360
\end{aligned}
$$

Untuk Bahan Baku lainnya fungsi kendala yang digunakan sama dengan bahan baku asam sulfat hanya saja berbeda dalam jumlah pemakaian yang digunakan untuk masing-masing produk sesuai dengan yang ditetapkan perusahaan.

\subsubsection{Merumuskan Fungsi Tujuan}

Berdasarkan pembatas-pembatas tujuan yang diuraikan diatas, maka fungsi tujuan dari model ini adalah :

$\mathrm{MIN}=$

DN01+DN02+DN03+DP04+DP05+DP0 6+DP07+DP08+DP09+DP10+DP11+D P12+DP13+DP14+DP15+DP16+DP17+ DP18+DP19+DP20+DP21+DP22+DP23 +DP24+DP25+DP26+DP27+DP28+DP 29+DP30+DP31+DP32+DP33+DP34+D P35+DP36+DP37+DP38+DP39+DP40+ DP41+DP42+DP43+DP44+DP45+DP46 +DP47+DP48+DP49+DP50+DP51+DP 
52+DP53+DP54+DP55+DP56+DP57+D

P58+DP59+DP60+DP61+DP62+DP63+

DP64+DP65+DP66+DP67+DP68+DP69

+DP70+DP71+DP72+DP73+DP74+DP

75+DP76+DP77+DP78+DP79+DP80+D

P81+DP82+DP83+DP84+DP85+DP86+

DP87+DP88+DP89+DP90+DP91+DP92 +DP93;

\subsubsection{Menentukan Prioritas dan Bobot}

Prioritas ini ditentukan dengan hasil wawancara kepada pihak perusahaan yaitu bapak Kevin Esmunaldo selaku staff pengendalian produksi dan di validasi oleh bapak Ujang Suryana.

Tabel 4.15 Tabel Urutan Prioritas

\begin{tabular}{|l|c|}
\hline \multicolumn{1}{|c|}{ Sasaran } & Prioritas \\
\hline Memaksimalkan ketersediaan hari kerja mesin & 1 \\
\hline Mengurangi kelebihan bahan baku & 2 \\
\hline Memenuhi target produksi yang telah direncanakan & 3 \\
\hline
\end{tabular}

Sehingga prioritasnya dapat dilihat pada tabel 4.22.

Tabel 4.16 Tabel Nilai Prioritas

\begin{tabular}{|l|c|}
\hline \multicolumn{1}{|c|}{ Produk } & $\begin{array}{c}\text { Nilai } \\
\text { Prioritas }\end{array}$ \\
\hline Memaksimalkan ketersediaan hari kerja mesin & 3 \\
\hline Mengurangi kelebihan bahan baku & 2 \\
\hline Memenuhi target produksi yang telah direncanakan & 1 \\
\hline
\end{tabular}

Dengan prioritas yang telah

ditetapkan pada tabel 4.22, maka fungsi tujuan model Goal programming ini dapat dirumuskan sebagai berikut :
$\mathrm{MIN}=$

$1 * \mathrm{DN} 01+1 * \mathrm{DN} 02+1 * \mathrm{DN} 03+3 * \mathrm{DP} 04+3$

*DP05+3*DP06+3*DP07+3*DP08+3*

$\mathrm{DP} 09+3 * \mathrm{DP} 10+3 * \mathrm{DP} 11+3 * \mathrm{DP} 12+3 * \mathrm{D}$

$\mathrm{P} 13+3 * \mathrm{DP} 14+3 * \mathrm{DP} 15+3 * \mathrm{DP} 16+3 * \mathrm{DP} 1$

$7+3 * \mathrm{DP} 18+3 * \mathrm{DP} 19+3 * \mathrm{DP} 20+3 * \mathrm{DP} 21+$ $3 * \mathrm{DP} 22+3 * \mathrm{DP} 23+3 * \mathrm{DP} 24+3 * \mathrm{DP} 25+3 *$ DP26+3*DP27+3*DP28+3*DP29+3*D $\mathrm{P} 30+3 * \mathrm{DP} 31+3 * \mathrm{DP} 32+3 * \mathrm{DP} 33+3 * \mathrm{DP} 3$ $4+3 * \mathrm{DP} 35+3 * \mathrm{DP} 36+3 * \mathrm{DP} 37+3 * \mathrm{DP} 38+$ $3 * \mathrm{DP} 39+2 * \mathrm{DP} 40+2 * \mathrm{DP} 41+2 * \mathrm{DP} 42+2 *$ $\mathrm{DP} 43+2 * \mathrm{DP} 44+2 * \mathrm{DP} 45+2 * \mathrm{DP} 46+2 * \mathrm{D}$ $\mathrm{P} 47+2 * \mathrm{DP} 48+2 * \mathrm{DP} 49+2 * \mathrm{DP} 50+2 * \mathrm{DP} 5$ $1+2 * \mathrm{DP} 52+2 * \mathrm{DP} 53+2 * \mathrm{DP} 54+2 * \mathrm{DP} 55+$ $2 * \mathrm{DP} 56+2 * \mathrm{DP} 57+2 * \mathrm{DP} 58+2 * \mathrm{DP} 59+2 *$ $\mathrm{DP} 60+2 * \mathrm{DP} 61+2 * \mathrm{DP} 62+2 * \mathrm{DP} 63+2 * \mathrm{D}$ $\mathrm{P} 64+2 * \mathrm{DP} 65+2 * \mathrm{DP} 66+2 * \mathrm{DP} 67+2 * \mathrm{DP} 6$ $8+2 * \mathrm{DP} 69+2 * \mathrm{DP} 70+2 * \mathrm{DP} 71+2 * \mathrm{DP} 72+$ $2 * \mathrm{DP} 73+2 * \mathrm{DP} 74+2 * \mathrm{DP} 75+2 * \mathrm{DP} 76+2 *$ DP77+2*DP78+2*DP79+2*DP80+2*D $\mathrm{P} 81+2 * \mathrm{DP} 82+2 * \mathrm{DP} 83+2 * \mathrm{DP} 84+2 * \mathrm{DP} 8$ $5+2 * \mathrm{DP} 86+2 * \mathrm{DP} 87+2 * \mathrm{DP} 88+2 * \mathrm{DP} 89+$ $2 * \mathrm{DP} 90+2 * \mathrm{DP} 91+2 * \mathrm{DP} 92+2 * \mathrm{DP} 93$;

\section{KESIMPULAN}

Hasil perencanaan optimalisasi produksi pupuk Phonska Subsidi, NPK Kebomas dan Phonska Plus pada periode Januari-Desember 2019 dengan menggunakan software Lingo 17.0 pada masing-masing pabrik adalah sebagai berikut : 
Tabel 5.1 Jumlah produksi pupuk Phonska subsidi di Pabrik NPK Phonska I,II dan III

\begin{tabular}{|c|c|c|c|c|}
\hline produk & periode & $\begin{array}{c}\text { pabrik NPK } \\
\text { Phonska I }\end{array}$ & $\begin{array}{c}\text { Pabrik NPK } \\
\text { Phonska II }\end{array}$ & $\begin{array}{c}\text { Pabrik NPK } \\
\text { Phonska III }\end{array}$ \\
\hline $\begin{array}{c}\text { Phonska } \\
\text { Subsidi }\end{array}$ & 1 & 40.500 & 0 & $25.851,85$ \\
\cline { 2 - 5 } & 2 & 36.000 & 47.000 & 0 \\
\cline { 2 - 5 } & 3 & 40.500 & 53.000 & $15.606,45$ \\
\cline { 2 - 5 } & 4 & 39.000 & 51.000 & 52.000 \\
\cline { 2 - 5 } & 5 & 40.500 & 53.000 & 54.000 \\
\cline { 2 - 5 } & 6 & 39.000 & $3.133,034$ & 52.000 \\
\cline { 2 - 5 } & 7 & 40.500 & 53.000 & 54.000 \\
\cline { 2 - 5 } & 8 & 40.500 & 53.000 & 54.000 \\
\cline { 2 - 5 } & 10 & 39.000 & $1.864,662$ & 52.000 \\
\cline { 2 - 5 } & 11 & 39.000 & 0 & 10.000 \\
\cline { 2 - 5 } & 12 & 26.500 & 0 & 52.000 \\
\hline TOTAL & & & 1.211 .456 & 54.000 \\
\hline DN & & & 0 & \\
\hline TARGET & & & 0 & \\
\hline
\end{tabular}

Tabel 5.2 Jumlah produksi pupuk NPK Kebomas di Pabrik NPK Phonska I,II dan III

\begin{tabular}{|c|c|c|c|c|}
\hline Produk & periode & $\begin{array}{c}\text { pabrik } \\
\text { NPK } \\
\text { Phonska } \\
\text { I }\end{array}$ & $\begin{array}{c}\text { Pabrik } \\
\text { NPK } \\
\text { Phonska } \\
\text { II }\end{array}$ & $\begin{array}{c}\text { Pabrik } \\
\text { NPK } \\
\text { Phonska } \\
\text { III }\end{array}$ \\
\hline \multirow{12}{*}{$\begin{array}{c}\text { NPK } \\
\text { Kebomas }\end{array}$} & 1 & 0 & 0 & 0 \\
\hline & 2 & 0 & 0 & 0 \\
\hline & 3 & 36.000 & 0 & $28.795,16$ \\
\hline & 4 & 0 & 0 & 0 \\
\hline & 5 & 0 & 0 & 0 \\
\hline & 6 & 0 & 0 & 0 \\
\hline & 7 & 0 & 0 & 0 \\
\hline & 8 & 0 & 0 & 0 \\
\hline & 9 & 0 & $36.851,5$ & 0 \\
\hline & 10 & 0 & 6.000 & 0 \\
\hline & 11 & 0 & 38.250 & 0 \\
\hline & 12 & 11.200 & $25.880,95$ & 0 \\
\hline TOTAL & \multicolumn{4}{|c|}{182.978} \\
\hline
\end{tabular}

\begin{tabular}{|c|c|}
\hline DN & 0 \\
\hline TARGET & 182.978 \\
\hline
\end{tabular}

Tabel 5.3 Jumlah produksi pupuk

Phonska Plus di Pabrik NPK Phonska I,II dan III

\begin{tabular}{|c|c|c|c|c|}
\hline Produk & periode & $\begin{array}{c}\text { pabrik } \\
\text { NPK } \\
\text { Phonska I }\end{array}$ & $\begin{array}{c}\text { Pabrik } \\
\text { NPK } \\
\text { Phonska } \\
\text { II }\end{array}$ & $\begin{array}{c}\text { Pabrik } \\
\text { NPK } \\
\text { Phonska } \\
\text { III }\end{array}$ \\
\hline \multirow{12}{*}{$\begin{array}{c}\text { Phonska } \\
\text { Plus }\end{array}$} & 1 & 0 & $6.055,556$ & 19.000 \\
\hline & 2 & 0 & 0 & 0 \\
\hline & 3 & 0 & 0 & 0 \\
\hline & 4 & 0 & 0 & 0 \\
\hline & 5 & 0 & 0 & 0 \\
\hline & 6 & 0 & 0 & 0 \\
\hline & 7 & 0 & 0 & 0 \\
\hline & 8 & 0 & 0 & 0 \\
\hline & 9 & 0 & 0 & 0 \\
\hline & 10 & 0 & 0 & 0 \\
\hline & 11 & $15.572,33$ & 0 & 0 \\
\hline & 12 & 0 & $12.944,44$ & 0 \\
\hline TOTAL & \multicolumn{4}{|c|}{53.572} \\
\hline $\mathrm{DN}$ & \multicolumn{4}{|c|}{0} \\
\hline TARGET & \multicolumn{4}{|c|}{53.572} \\
\hline
\end{tabular}

\section{SARAN}

\subsection{Untuk Perusahaan}

Untuk PT. Petrokimia Gresik dapat meengetahui jumlah optimal dalam produksi Phonska Subsidi, NPK Kebomas, Phonska Plus dengan menggunakan metode goal programming, sedangkan untuk mengetahui jumlah permintaan pada tahun berikutnya perusahaan dapat menggunakan metode peramalan time series seperti Winter's, single 
exponential smoothing dan double exponential smoothing.

\subsection{Untuk Peneliti Selanjutnya}

1. Di dalam penelitian ini obyek pengamatan hanya pada pabrik NPK Phonska I,II dan III departemen II A PT.Petrokimia Gresik, untuk penelitian selanjutnya bisa lebih meluaskan ruang lingkup di perusahaan PT.Petrokimia Gresik.

2. Dalam penelitian ini hanya menambahkan fungsi kendala ketersediaan hari kerja mesin dan bahan baku, untuk penelitian selanjutnya bisa menambahkan fungsi kendala lainnya seperti biaya, tenaga kerja, dll.

\section{DAFTAR PUSTAKA}

Amalia, R. (2016). Penerapan Metode Goal Programming untuk Optimasi Biaya Produksi pada Produk Air Mineral Aqua di Bangkalan. Math Journal, 28-33.

Fahmi, G. D. (2018). Penerapan Metode Goal Programming dan Integer Programming untuk Menentukan Jumlah Produk yang Optimal. SKRIPSI Program Studi Teknik Industri, Universitas Muhammadiyah Gresik.

Ginting, R. (2007). Sistem Produksi. Yogyakarta: Graha Ilmu.

Indrawati, d. (2017). Optimalisasi Model Cloud Radio Acceess Network (CRan) pada Efisiensi Konsumsi Bandwidth dalam Jaringan. Computer Science and ICT, 117120.
Meyhard Sualang, N. J. (2018). Optimalisasi Produksi Air Bersih Pelanggan PT. Air Manado Menggunakan Metode Goal Programming. Jurnal Matematika dan Aplikasi deCartesia, 29-34.

Mulyono, S. (2014). Riset Operasi Edisi 2. Jakarta: Mitra Wacana Media.

Prasetyawan, A. H. (2008). Perencanaan \& Pengendalian Produksi. Yogyakarta: Graha Ilmu.

Ristono, P. d. (2012). Penelitian Operasional. Yogyakarta: Graha Ilmu.

Rizqiyah, I. Z. (2018). Penentuan Tonase Pemesanan Bahan Baku Pupuk Organik kepada Supplier dengan Metode Goal Programming (Studi Kasus : PT. Petrokimia Gresik. SKRIPSI Program Studi Teknik Industri, Universitas Muhammadiyah Gresik.

Sari, N. M. (2017). Penentuan Ukuran Pemesanan Bahan Baku Stainless Steel Multi Item Supplier dengan Goal Programming (Studi kasus: PT. Jindal Stainless Indonesia). SKRIPSI Program Studi Teknik Industri, Universitas Muhammadiyah Gresik.

Tribunnews. (2018, Agustus 08). Retrieved Oktober 17, 2018, from Tribunnews.com: http://www.tribunnews.com/nasion al/2018/08/08/ekonomi-indonesiatriwulan-ii-2018-tumbuh-421lapangan-usaha-pertanian-palingtinggi 